\title{
STRUKTUR KOMUNITAS IKAN KARANG DI PERAIRAN KABUPATEN BANGGAI KEPULAUAN, SULAWESI TENGAH
}

\author{
Isa Nagib Edrus") dan Guridno Bintar Saputro") \\ 1) Peneliti pada Balai Riset Perikanan Laut, Muara Baru-Jakarta \\ 2) Peneliti pada Badan Koordinasi Survei dan Pemetaan Nasional, Cibinong-Bogor \\ Teregistrasi I tanggal: 28 Oktober 2008; Diterima setelah perbaikan tanggal: 17 Pebruari 2009; \\ Disetujui terbit tanggal: 13 Mei 2009
}

\begin{abstract}
ABSTRAK
Perubahan habitat karang adalah resiko yang mungkin dihadapi sebagai akibat pembangunan. Keanekaragaman ikan karang merupakan suatu indikator penting yang dapat memberikan gambaran perubahan pada lingkungan perairan karang. Tujuan penelitian ini adalah untuk mengetahui berbagai indeks ekologis komunitas ikan karang. Data ikan karang dikumpulkan dengan metode sensus visual pada daerah seluas $100 \mathrm{~m}^{2}$. Hasil penelitian menunjukkan bahwa indeks kekayaan $\left(R_{1}\right)$ ikan karang terkecil 4,47 dan terbesar 16,61. Kondisi keanekaragaman ikan karang masuk pada kategori sedang pada 21 lokasi (dengan indeks $H: 2,65-3,44$ ), kategori tinggi pada 11 lokasi $(H: 3,48-3,88$ ), dan kategori rendah pada 1 lokasi $(\mathrm{H}: 2,08)$. Indeks dominansi (D) masuk pada kategori rendah dan indeks keseragaman (E) masuk pada kategori tinggi untuk semua lokasi. Indeks jumlah koloni (N1 dan N2) relatif besar, variasinya terkecil 8,03 dan 4,81, dan terbesar 48,63 dan 32,58 . Kelompok ikan karang mayor mendominansi komunitas ikan karang. Persentase kelompok ikan indikator tergolong kecil, kecuali untuk 1 lokasi. Potensi ikan target niaga cukup tinggi. Kepadatan ikan karang tergolong jarang, yaitu di bawah 10 ind. $/ \mathrm{m}^{2}$. Nilai dari Indeks-indeks tersebut menunjukkan bahwa lingkungan perairan karang di Kabupaten Banggai Kepulauan pada umumnya dalam kondisi baik.
\end{abstract}

KATAKUNCI: ikan karang, indeks keanekargaman, potensi, perairan karang, Kabupaten Banggai Kepulauan

ABSTRACT: Community structure of reef fish in the waters of Banggai Archipelago County, Central Sulawesi. By: Isa Nagib Edrus and Guridno Bintar Saputro

Economic developments probably lead to habitat alteration risks. Reef fish diversity is a major indicator to expose a current environmental state of coral reefs. The study objective is to fine out several diversity indices of reef fish communities. The data of reef fish was gathered by using a visualcensus transect method for the reef sites of 100 square meters in areas. The results show that richness indices (R1) of reef fish ranged from the lowest of 4.47 to the highest of 16.61. Shannon diversity indices of reef fish felt in the fair category for 21 study sites (indices $\mathrm{H:}$ : 65-3.44), in the high category for 11 study sites (H: 3.48-3.88), and in the low category for one study site (H:2.08). Dominance Indices (D) of reef fish felt in a low category and evenness indices felt in a high category for all study sites. Hill's Diversity number (N1 and N2) included in high category, the lowest varied from 8.03-4.81 and the highest varied from 48.63-32.58. The major fish groups were predominant among reef fish community. Percentages of indicator fish species felt in low areas for all the study sites, except one the study site. Potencies of marketable-target fish were high enough. Reef fish densities were grouped in rare areas, especially $<10$ ind. $/ \mathrm{m}^{2}$. Generally, the index rates indicated well for reef water environments of the Banggai Archipelago.

KEYWORDS: reef fish, diversity indices, potency, reef waters, Banggai Archipelago, Central Sulawesi

\section{PENDAHULUAN}

Terumbu karang mendukung keanekaragaman organisme dan habitat. Keragaman pada umumnya dibentuk oleh banyak variasi antara lain 1) jenis ikan yang diperkirakan lebih dari 4.000 spesies; 2) biota lain non ikan yang tergolong sponge, cnidaria, cacing, krustacea, moluska, ekinodermata, cumi-cumi, penyu, dan ular laut; 3 ) jenis karang dan bentuk tumbuh kehidupan karang; 4) mikro habitat, celah, liang, atau relung (niche); 5) tipe rantai makanan dan jenis makanan, dan 6) bentuk-bentuk simbion antar jenis (Castro \& Huber, 2000; Nybakken, 1992; Spalding et al., 2001). Jadi keanekaragaman ikan karang dalam tingkat komunitas adalah sebagai akibat dari adanya keanekaragaman hayati sumber daya, keragaman makanan, habitat, relung, dan interaksi antar spesies. Dalam pengertian aplikasi petunjuk keanekaragaman diperlihatkan oleh distribusi dari jumlah masing-masing populasi ikan itu sendiri. Jika lokasi A memiliki 1 
individu $x$ dan 99 individu $y$, sedang lokasi $B$ memiliki 50 individu $x$ dan 50 individu y, maka lokasi $B$ dikatakan lebih beragam dibanding lokasi $A$. Menurut pengertian ini dapat diasumsikan bahwa keanekaragaman akan terbentuk jika lingkungannya secara merata mendukung semua organisme untuk mengembangkan populasinya dan terbentuk keseimbangan populasi. Sebaliknya dominansi jenis menunjukkan adanya sesuatu yang ekstrim dalam lingkungan, seperti adanya polusi atau sedimentasi (Gray, 1997; Lieske \& Myers, 1997; Nybakken, 1992). Dengan demikian, keanekaragaman ikan karang dapat menjadi indikator pada perubahan lingkungan.

Oleh karena keanekaragaman dalam terumbu karang sangat tinggi dan ancaman kerusakan pada habitat karang ini juga sangat tinggi. Pemerintah memiliki kepentingan untuk menentukan arah kebijakan pengembangan sektor perikanan pesisir dan menentukan tindakan yang tepat dalam cara pengelolaan agar pemanfaatannya dapat berkesinambungan. Seperti perlunya konservasi sumber daya karang (Gray, 1997) dan perlunya perlindungan 2 jenis ikan karang yang bernilai ekonomis tinggi dan endemik yang diasumsikan terancam punah, contohnya ikan banggai kardinal (Pterapogon kaudermi) dan napoleon (Cheilinus undulatus) (Rhu, 2008; Soehartono \& Mardiastuti, 2003).

Menurut Gomez \& Yap (1984), informasi ekologis yang berhubungan dengan kejadian perubahan lingkungan perairan karang dapat membantu penyusunan kebijakan. Indeks-indeks keanekaragaman komunitas secara temporal dapat menggambarkan peningkatan mutu lingkungan perairan karang atau sebaliknya penurunan mutu atau kerusakkan lingkungan perairan karang. Dalam hal ini, komunitas ikan dapat dijadikan indikator karena memberikan respon yang paling cepat atas perubahan kondisi habitatnya. Dengan demikian, indeks-indeks keanekaragaman komunitas ikan karang sering diaplikasikan sebagaı indikator dalam proses monitoring dan evaluasi. Menurut Odum (1975) informasi keanekeragaman komunitas dalam ekosistem perairan terumbu karang dapat menggambarkan kestabilan ekosistem tersebut atau sebaliknya.

Tujuan penelitian ini adalah untuk mengetahui berbagai indeks ekologis komunitas ikan karang yang meliputi kekayaan jenis, keanekaragaman jenis, kemerataan populasi, dominansi dan kepadatan ikan, serta persentase kelompok ikan karang berdasarkan pada jumlah individu dan jumlah jenisnya.

\section{BAHAN DAN METODE}

Survei dilaksanakan pada bulan Mei 2007 di wilayah perairan karang Kabupaten Banggai Kepulauan, Sulawesi Tengah. Letak geografis Kabupaten ini antara $1^{\circ} 06^{\prime} 30^{\prime \prime}$ LS $-2^{\circ} 20^{\prime} 00^{\prime \prime}$ LS dan $122^{\circ} 40^{\prime} 00 \mathrm{BT}-124^{\circ} 05^{\prime} 00 \mathrm{BT}$. Stasiun penelitian dipilih berdasarkan pada analisis peta kerja yang disiapkan dari citra satelit (Gambar 1).

Pendekatan dalam pengambilan data adalah dengan cara rapid reef assessment dan sensus visual. Lokasi untuk penempatan transek rapid reef assessment ditentukan 32 titik transek, di mana pada setiap titik transek tersebut ditentukan posisi geografisnya (Tabel 1).

Pengambilan data ikan karang dengan metode rapid reef assessment dilakuan dengan cara snorkling pada titik transek rapid reef assessment yang sudah ditentukan dengan luas sensus $100 \mathrm{~m}^{2}$ selama 15 menit. Jenis dan perkiraan jumlah ikan dicatat dalam data sheet kedap air. Identifikasi jenis ikan menggunakan buku petunjuk bergambar (Kuiter, 1992; Lieske \& Myers, 1997). Ikan karang dikelompokan menurut statusnya, seperti ikan indikator, ikan mayor, dan ikan target (English et al., 1994). Ikan indikator kebanyakan dari suku Chaetodontidae yang kehadirannya dapat merefleksikan kondisi kesehatan karang. Ikan mayor adalah golongan ikan hias dan non ikan hias yang selalu berasosiasi dengan karang, baik sebagai penetap maupun pelintas. Ikan target adalah dari golongan ikan yang dicari oleh nelayan untuk dimakan dan dijual

Analisis keragaman hayati ikan karang menggunakan beberapa indeks yang dianggap penting sebagai baseline data. Indeks-indeks itu adalah Indeks Kekayaan Jenis (Richness Indices), Indeks Keanekaragaman (Diversity indices), dan Indeks Keseragaman Jenis (Evenness Indices). Olah data dalam penggunaan rumus-rumus ini menggunakan prinsip Microsoft Excel yang telah diformat oleh Ludwig \& Reynold (1988).

1. Indeks Kekayaan Jenis mengacu pada:

$$
\begin{aligned}
& \text { Indeks Margalef: } R=(S-1) / L n(n) \ldots \ldots \ldots \ldots \ldots . . . . .(1 \\
& \text { di mana: } \\
& \qquad \begin{array}{l}
S=\text { banyaknya jenis } \\
N=\text { jumlah individu ikan untuk semua jenis }
\end{array}
\end{aligned}
$$

2. Indeks Keanekaragaman mengacu pada: 


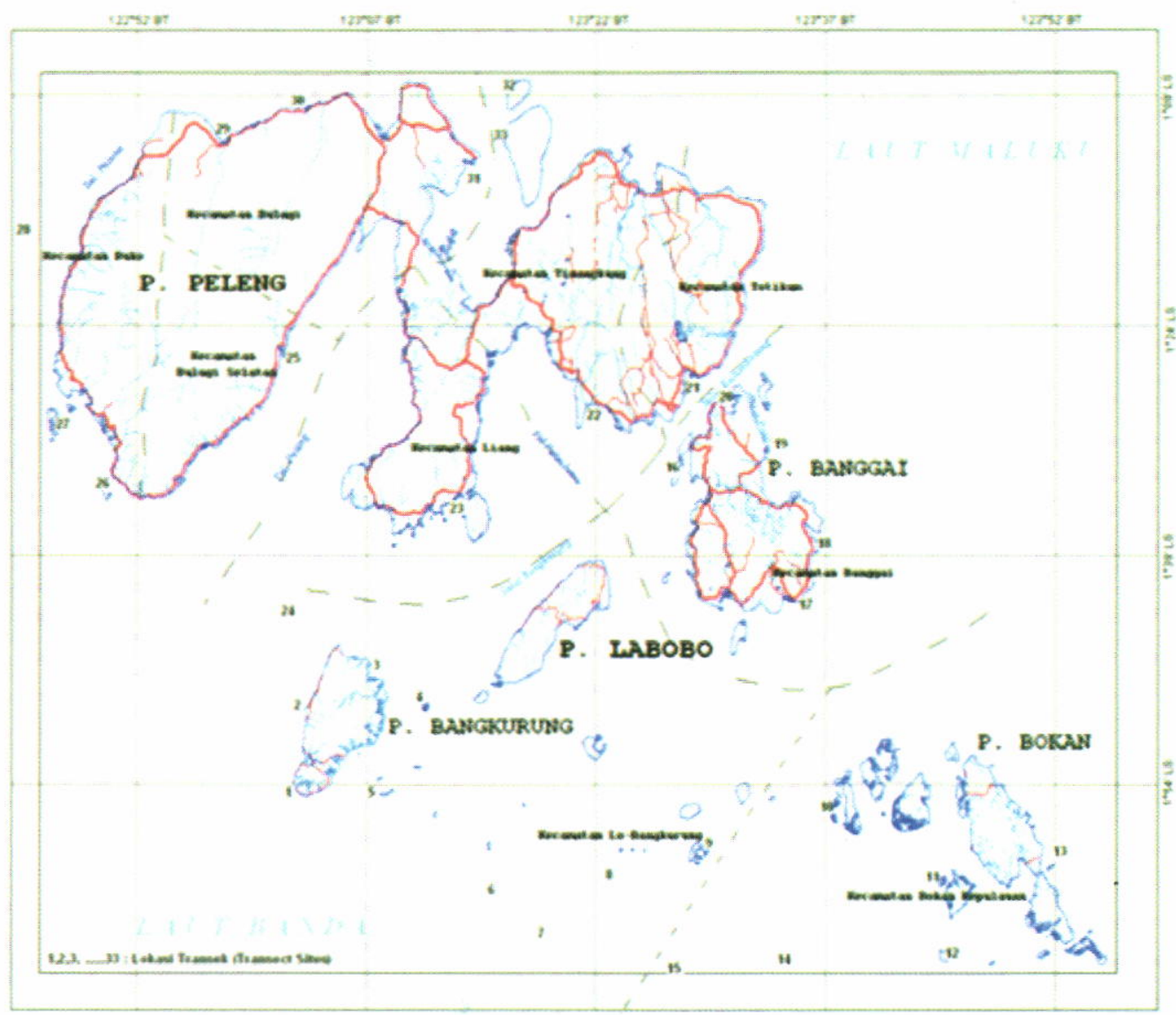

Gambar 1. Peta lokasi penelitian di Banggai Kepulauan, Sulawesi Tengah, yang menunjukkan lokasi transek.

Figure 1. A map showing transect sites of the study in Banggai Islands of Central Sulawesi.

Tabel 1. Posisi geografis dan administrasi lokasi transek ikan karang di Kabupaten Banggai Kepulauan

Table 1. Geographical and administrative positions of reef fish transect sites in Banggai Island

\begin{tabular}{|c|c|c|c|c|c|c|c|}
\hline \multirow{2}{*}{$\begin{array}{c}\text { Lokasi } \\
\text { transek/ } \\
\text { Transect } \\
\text { sites } \\
1\end{array}$} & \multicolumn{2}{|c|}{$\begin{array}{c}\text { Posisi geografis/ } \\
\text { Geographical positions }\end{array}$} & \multirow{2}{*}{$\begin{array}{c}\text { Nama wilayah/ } \\
\text { Area names } \\
\text { Taduno }\end{array}$} & \multirow{2}{*}{$\begin{array}{c}\begin{array}{c}\text { Lokasi } \\
\text { transek/ } \\
\text { Transect } \\
\text { sites }\end{array} \\
18\end{array}$} & \multicolumn{2}{|c|}{$\begin{array}{c}\text { Posisi geografis/ } \\
\text { Geographical positions }\end{array}$} & \multirow{2}{*}{$\begin{array}{c}\text { Nama wilayah/ } \\
\text { Area names }\end{array}$} \\
\hline & $01,92603^{\circ}$ & $123,06653^{\circ}$ & & & $01,63926^{\circ}$ & $123,61849^{\circ}$ & \\
\hline 2 & $01,82858^{\circ}$ & $123,05972^{\circ}$ & Tabulang & 19 & $01,55328^{\circ}$ & $123,56042^{\circ}$ & Kendek \\
\hline 3 & $01,79644^{\circ}$ & $123,13864^{\circ}$ & Bone-Bone & 20 & $01,48094^{\circ}$ & $123,51717^{\circ}$ & Pulau Popisi \\
\hline 4 & $01,80056^{\circ}$ & $123,18408^{\circ}$ & Pulau Bakau & 21 & $01,51596^{\circ}$ & $123,41768^{\circ}$ & Tundusun \\
\hline 5 & $01,92482^{\circ}$ & $123,14902^{\circ}$ & Tolobundo & 22 & $01,51837^{\circ}$ & $123,36055^{\circ}$ & Bobu \\
\hline 6 & $02,06146^{\circ}$ & $123,27857^{\circ}$ & Ganemo & 23 & $01,64900^{\circ}$ & $123,24223^{\circ}$ & Tj.Pinalang \\
\hline 7 & $02,09491^{\circ}$ & $123,32565^{\circ}$ & Silumba & 24 & $01,74025^{\circ}$ & $123,00641^{\circ}$ & Merpati \\
\hline 8 & $02,01101^{\circ}$ & $123,40670^{\circ}$ & Mandebolu & 25 & $01,40838^{\circ}$ & $123,04781^{\circ}$ & Unu \\
\hline 9 & $01,98806^{\circ}$ & $123,47717^{\circ}$ & Bulutan & 26 & $01,59125^{\circ}$ & $122,84636^{\circ}$ & Delapan \\
\hline 10 & $01,94207^{\circ}$ & $123,62978^{\circ}$ & Tropot & 27 & $01,48118^{\circ}$ & $122,78194^{\circ}$ & Sabalade \\
\hline 11 & $02,02649^{\circ}$ & $123,74844^{\circ}$ & Pulau Tongo & 28 & $01,33375^{\circ}$ & $122,75081^{\circ}$ & Pulau Tikus \\
\hline 12 & $02,10072^{\circ}$ & $123,76251^{\circ}$ & Tanalan & 29 & $01,19631^{\circ}$ & $122,91635^{\circ}$ & Lukpasateng \\
\hline 13 & $02,00403^{\circ}$ & $123,86633^{\circ}$ & Dendek & 30 & $01,16966^{\circ}$ & $123,07716^{\circ}$ & Sabang \\
\hline 14 & $02,05635^{\circ}$ & $123,59380^{\circ}$ & Pulau Jodoh & 31 & $01,23072^{\circ}$ & $123,24844^{\circ}$ & Montopo \\
\hline 15 & $02,11921^{\circ}$ & $123,45374^{\circ}$ & Pulau Burung & 32 & $01,17630^{\circ}$ & $123,27830^{\circ}$ & Bakalan Kecil \\
\hline 16 & $01,68486^{\circ}$ & $123,45190^{\circ}$ & Bandang & 33 & $01,21207^{\circ}$ & $123,32545^{\circ}$ & Bakalan Besar \\
\hline 17 & $01,71051^{\circ}$ & $123,60205^{\circ}$ & Matanga & & & & \\
\hline
\end{tabular}


Tabel 2 .

Kondisi komunitas ikan karang di perairan Banggai Kepulauan menurut lokasi

\begin{tabular}{|c|c|c|c|c|c|c|c|c|c|}
\hline \multirow{3}{*}{$\begin{array}{l}\text { Kategoril } \\
\text { Categories }\end{array}$} & \multicolumn{9}{|c|}{ Lokasi transek/Transect sites } \\
\hline & 1 & 2 & 3 & 4 & 5 & 6 & 7 & 8 & 9 \\
\hline & Taduno & Tabulang & Bone2 & P.Bakau & $\begin{array}{l}\text { Tolo } \\
\text { bundo }\end{array}$ & Ganemo & Silumba & $\begin{array}{c}\text { Mande } \\
\text { bolu }\end{array}$ & Bulutan \\
\hline \multicolumn{10}{|l|}{ Taksonomi/Taxonomy } \\
\hline Jumlah suku/Family number & 15 & 13 & 20 & 15 & 15 & 17 & 17 & 17 & 17 \\
\hline Jumlah marga/Genus number & 32 & 27 & 49 & 33 & 32 & 36 & 29 & 37 & 40 \\
\hline $\begin{array}{l}\text { Jumlah jenis/Spesies number } \\
\text { Kondisi Populasi Ikanl } \\
\text { Population Property }\end{array}$ & 48 & 47 & 84 & 55 & 50 & 60 & 41 & 61 & 60 \\
\hline $\begin{array}{l}\text { Indeks Kekayaan-R/ } \\
\text { Margalef's Indices }\end{array}$ & 8,27 & 8,43 & 13,47 & 8,73 & 8,01 & 9,91 & 6,63 & 9,69 & 9,08 \\
\hline $\begin{array}{l}\text { Indeks Dominansi (D)/ } \\
\text { Domination Indices }\end{array}$ & 0,09 & 0,05 & 0,05 & 0,05 & 0,07 & 0,05 & 0,1 & 0,04 & 0,08 \\
\hline $\begin{array}{l}\text { Indeks Keanekaragaman/ } \\
\text { Shannon Diversity Index }\end{array}$ & 2,92 & 3.37 & 3,56 & 3,26 & 3,08 & 3,38 & 2,67 & 3,5 & 3,1 \\
\hline $\begin{array}{l}\text { Jumiah gerombolan-N1/ } \\
\text { Hill's diversity number }\end{array}$ & 18,51 & 28,97 & 35,24 & 26,18 & 21,67 & 29,48 & 14,44 & 33,27 & 22,1 \\
\hline $\begin{array}{l}\text { Jumlah gerombolan-N2/ } \\
\text { Hill's diversity number }\end{array}$ & 10,56 & 21,4 & 19,57 & 18,67 & 13.99 & 21.66 & 9,81 & 24,69 & 12,11 \\
\hline $\begin{array}{l}\text { Indeks Keseragaman-E/ } \\
\text { Evenness Indices }\end{array}$ & 0,75 & 0,87 & 0,8 & 0,81 & 0.79 & 0,83 & 0,72 & 0,85 & 0,75 \\
\hline $\begin{array}{l}\text { Jumlah individu/ } \\
\text { Individual number }\end{array}$ & 294 & 234 & 475 & 486 & 454 & 386 & 418 & 488 & 666 \\
\hline $\begin{array}{l}\text { Kepadiatan/Density } \\
\text { (ind } . / \mathrm{m}^{2} \text { ) }\end{array}$ & 2,94 & 2,34 & 4.75 & 4,86 & 4.54 & 3,86 & 4,18 & 4,88 & 6,66 \\
\hline \multicolumn{10}{|l|}{$\begin{array}{l}\text { Komposisi/Composition } \\
\text { (Individual number) }\end{array}$} \\
\hline Ikan target-T/Target fishes (\%) & 7,14 & 9.4 & 19,37 & 8.44 & 13,00 & 18,65 & 4,55 & 34,84 & 8,41 \\
\hline Ikan mayor-MMajor fishes (\%) & 91,16 & 84,62 & 72,00 & 91,56 & 86,56 & 79,79 & 94,02 & 63,93 & 88,74 \\
\hline $\begin{array}{l}\text { Ikan indikator-l| } \\
\text { Indicator fishes }\langle \%\rangle\end{array}$ & 1,7 & 5,98 & 8,21 & 0,00 & 0,44 & 1,55 & 1,44 & 1,23 & 2,85 \\
\hline \multicolumn{10}{|l|}{$\begin{array}{l}\text { Komposisi/Composition } \\
\text { (Species number) }\end{array}$} \\
\hline Ikan target-T/Target fishes (\%) & 25,00 & 19,15 & 30,95 & 27,27 & 30,00 & 31,67 & 21,95 & 34,43 & 28,33 \\
\hline Ikan mayor-M/Major fishes (\%) & 70,83 & 70,21 & 53,57 & 72,73 & 68,00 & 63,33 & 68,29 & 59,02 & 61,67 \\
\hline $\begin{array}{l}\text { Ikan indikator-l/ } \\
\text { Indicator fishes (\%) }\end{array}$ & 4,17 & 10,64 & 14.29 & 0,00 & 2,00 & 5,00 & 9.76 & 6,56 & 10,00 \\
\hline \multirow{3}{*}{$\begin{array}{l}\text { Kategoril } \\
\text { Categories }\end{array}$} & \multicolumn{9}{|c|}{ Lokasi transek/Transect sites } \\
\hline & 10 & 11 & 12 & 13 & 14 & 15 & 16 & 17 & 18 \\
\hline & Tropot & P. Tongo & Tanalan & Dendek & P. Jodoh & P. Burung & Bandang & Matanga & Umbuli \\
\hline $\begin{array}{l}\text { Taksonomi/raxonomy } \\
\text { Jumlah suku/Family number }\end{array}$ & & & & & & & & & \\
\hline $\begin{array}{l}\text { Jumlah suku/Family number } \\
\text { Jumlah marga/Genus number }\end{array}$ & 17 & 16 & 11 & 12 & 17 & 15 & 24 & 15 & 21 \\
\hline $\begin{array}{l}\text { Jumlah marga/Genus number } \\
\text { Jumlah jenis/Spesies number }\end{array}$ & 39 & 36 & 25 & 33 & 40 & 32 & 54 & 32 & 48 \\
\hline $\begin{array}{l}\text { Jumlah jenis/Spesies number } \\
\text { Kondisi Populasi Ikan/ }\end{array}$ & 51 & 54 & 35 & 60 & 56 & 52 & 86 & 46 & 82 \\
\hline \multicolumn{10}{|l|}{$\begin{array}{l}\text { Kondisi Populasi Ikan/ } \\
\text { Population Property }\end{array}$} \\
\hline $\begin{array}{l}\text { Indeks Kekayaan-R/ } \\
\text { Margalef's Indices }\end{array}$ & 8,32 & 8,94 & 6,07 & 8,68 & 8,81 & 9,24 & 12,37 & 8,31 & 13,21 \\
\hline $\begin{array}{l}\text { Indeks Dominansi (D)/ } \\
\text { Domination Indices }\end{array}$ & 0,07 & 0.07 & 0,13 & 0,12 & 0,17 & 0,06 & 0,05 & 0,05 & 0.03 \\
\hline $\begin{array}{l}\text { Indeks Keanekaragaman/ } \\
\text { Shannon Diversity Index }\end{array}$ & 3,03 & 3,2 & 2,65 & 2,73 & 2,79 & 3,22 & 3,48 & 3,34 & 3,76 \\
\hline $\begin{array}{l}\text { Jumlah gerombolan-N1/ } \\
\text { Hill's diversitry number }\end{array}$ & 20,79 & 24,62 & 14,19 & 15,28 & 16,25 & 24,97 & 32,62 & 28,16 & 43,06 \\
\hline $\begin{array}{l}\text { Jumlah gerombolan-N2/ } \\
\text { Hill's diversitry number }\end{array}$ & 13,93 & 14,42 & 7,94 & 8,53 & 6,03 & 16,72 & 18,3 & 20,69 & 29,2 \\
\hline $\begin{array}{l}\text { Indeks Keseragaman-E/ } \\
\text { Evenness Indices }\end{array}$ & 0,77 & 0,8 & 0,75 & 0,67 & 0,69 & 0,81 & 0,78 & 0,87 & 0,85 \\
\hline $\begin{array}{l}\text { Jumlah individu/ } \\
\text { Individual number }\end{array}$ & 407 & 375 & 270 & 897 & 516 & 250 & 889 & 225 & 460 \\
\hline
\end{tabular}


Tabel 2. Lanjutan

Table 2. Continue

\begin{tabular}{|c|c|c|c|c|c|c|c|c|c|}
\hline \multirow{3}{*}{$\begin{array}{l}\text { Kategoril } \\
\text { Categories }\end{array}$} & \multicolumn{9}{|c|}{ Lokasi transek/Transect sites } \\
\hline & 10 & 11 & 12 & 13 & 14 & 15 & 16 & 17 & 18 \\
\hline & Tropot & P. Tongo & Tanalan & Dendek & P. Jodoh & P. Burung & Bandang & Matanga & a Umbuli \\
\hline $\begin{array}{l}\text { Kepadatan/Density } \\
\text { (ind. } / \mathrm{m}^{2} \text { ) }\end{array}$ & 4,07 & 3,75 & 2,7 & 8,97 & 5,16 & 2,5 & 8,89 & 2,25 & 4,6 \\
\hline \multicolumn{10}{|l|}{$\begin{array}{l}\text { Komposisi/Composition } \\
\text { Individual number }\end{array}$} \\
\hline Ikan target-T/Target fishes (\%) & 25,8 & 17,07 & 8,89 & 2,68 & 13,95 & 10,00 & 9,45 & 11,11 & 18,26 \\
\hline Ikan mayor-M/Major fishes (\%) & 57,49 & 70.13 & 80,37 & 95,99 & 77,13 & 87,6 & 86,5 & 80,89 & 75,65 \\
\hline $\begin{array}{l}\text { Ikan indikator-I/ } \\
\text { Indicator fishes (\%) }\end{array}$ & 3,44 & 12,8 & 10,74 & 1,11 & 8,91 & 2,4 & 3,82 & 8,00 & 6,09 \\
\hline \multicolumn{10}{|l|}{$\begin{array}{l}\text { Komposisi/Composition } \\
\text { (Species number) }\end{array}$} \\
\hline Ikan target-T/Target fishes (\%) & 33,33 & 29,63 & 17,14 & 25,00 & 39,29 & 32,69 & 26,74 & 26,09 & 34,15 \\
\hline Ikan mayor-M/Major fishes (\%) & 58,82 & 53,7 & 62,86 & 65,00 & 50,00 & 65,38 & 62,79 & 67,39 & 51,22 \\
\hline $\begin{array}{l}\text { Ikan indikator-I/ } \\
\text { Indicator fishes (\%) }\end{array}$ & 7,84 & 16,67 & 20,00 & 8,33 & 10,71 & 1,92 & 9,3 & 6,52 & 14,63 \\
\hline \multirow{3}{*}{$\begin{array}{l}\text { Kategori/ } \\
\text { Categories }\end{array}$} & \multicolumn{9}{|c|}{ Lokasi transek/Transect sites } \\
\hline & 19 & 20 & 21 & 22 & 23 & 24 & 25 & 26 & 27 \\
\hline & Kendek & P. Popisi & $\begin{array}{l}\text { Tund } \\
\text { usun }\end{array}$ & Bobu & $\begin{array}{c}\mathrm{Tj} . \\
\text { Pinalang }\end{array}$ & Merpati & Unu & Delapan $\mathbf{S}$ & Sabalade \\
\hline Taksonomi/Taxonomy & & & & & & & & & \\
\hline Jumlah suku/Family number & 14 & 15 & 10 & 10 & 20 & 25 & 17 & 17 & 28 \\
\hline Jumlah marga/Genus number & 35 & 28 & 17 & 20 & 44 & 58 & 34 & 42 & 59 \\
\hline $\begin{array}{l}\text { Jumlah jenis/Spesies number } \\
\text { Kondisi Populasi Ikan/ } \\
\text { Population Property }\end{array}$ & 54 & 48 & 25 & 34 & 84 & 100 & 50 & 76 & 85 \\
\hline $\begin{array}{l}\text { Indeks Kekayaan-R/ } \\
\text { Margalef's Indices }\end{array}$ & 9,75 & 8,03 & 4,47 & 5,56 & 12,05 & 14,95 & 8,61 & 11,87 & 13.23 \\
\hline $\begin{array}{l}\text { Indeks Dominansi (D)/ } \\
\text { Domination Indices }\end{array}$ & 0,03 & 0,07 & 0,21 & 0,1 & 0,06 & 0.04 & 0.08 & 0.04 & 0.05 \\
\hline $\begin{array}{l}\text { Indeks Keanekaragaman/ } \\
\text { Shannon Diversity Index }\end{array}$ & 3,55 & 3,09 & 2,08 & 2,68 & 3,41 & 3,65 & 3,07 & 3,55 & 3,49 \\
\hline $\begin{array}{l}\text { Jumlah gerombolan-N1/ } \\
\text { Hill's diversitry number }\end{array}$ & 34,73 & 22.07 & 8.03 & 14,59 & 30,41 & 38.49 & & & \\
\hline $\begin{array}{l}\text { Jumlah gerombolan-N2/ } \\
\text { Hill's diversitry number }\end{array}$ & 26,31 & 13,34 & 4.81 & 9,64 & 15,41 & 22.86 & 21,49 & 34,69 & 32,93 \\
\hline $\begin{array}{l}\text { Indeks Keseragaman-E/ } \\
\text { Evenness /ndices }\end{array}$ & 0,89 & 0.8 & 0,65 & 0,76 & 0.77 & 0.79 & 13,18 & 23,15 & 20,32 \\
\hline Jumlah individu/ & & & & & & & & 0,02 & 0,8 \\
\hline Individual number & 230 & 346 & 215 & 377 & 979 & 752 & 296 & 556 & 571 \\
\hline $\begin{array}{l}\text { Kepadatan/Density } \\
\text { (ind./m²) } \\
\text { Komposisi/Composition } \\
\text { (Individual number) }\end{array}$ & 2,3 & 3,46 & 2,15 & 3,77 & 9,79 & 7,52 & 2,96 & 5,56 & 5,71 \\
\hline Ikan target-T/Target fishes (\%) & 12,17 & 12,43 & 0,93 & 19,1 & 39,3 & 13,43 & 17,9 & 17,27 & 7,00 \\
\hline Ikan mayor-M/Major fishes (\%) & 79,57 & 82,95 & 98,6 & 80,37 & 58,63 & 84,44 & 79,39 & 81,12 & 92,29 \\
\hline $\begin{array}{l}\text { Ikan indikator-l/ } \\
\text { Indicator fishes (\%) } \\
\text { Komposisi/Composition } \\
\text { (Species number) }\end{array}$ & 8,26 & 4,62 & 0,47 & 0,53 & 2,04 & 2,13 & 2,7 & 1,62 & 0,7 \\
\hline Ikan target-T/Target fishes (\%) & 14,81 & 31,25 & 8,00 & 29,41 & 39,29 & 34,00 & 46,00 & 31,58 & 23,53 \\
\hline Ikan mayor-M/Major fishes (\%) & 70,37 & 62,50 & 88,00 & 67,65 & 53,57 & 58,00 & 48,00 & 61,84 & 74,12 \\
\hline $\begin{array}{l}\text { Ikan indikator-I/ } \\
\text { Indicator fishes (\%) }\end{array}$ & 14,81 & 6,25 & 4,00 & 2,94 & 7,14 & 8,00 & 6,00 & 6,58 & 2,35 \\
\hline
\end{tabular}


Tabel 2.

Lanjutan

Tabie 2

Continue

\begin{tabular}{|c|c|c|c|c|c|c|}
\hline \multirow{3}{*}{$\begin{array}{l}\text { Kategori/ } \\
\text { Categories }\end{array}$} & \multicolumn{6}{|c|}{ Lokasi transek/Transect sites } \\
\hline & 28 & 29 & 30 & 31 & 32 & 33 \\
\hline & P.Tikus & Lukpasateng & Sabang & Montopo & Bakalan Kecil & $\begin{array}{c}\text { Bakalan } \\
\text { Besar }\end{array}$ \\
\hline \multicolumn{7}{|l|}{ Taksonomi/Taxonomy } \\
\hline Jumlah suku/Family number & 20 & 22 & 28 & 21 & 20 & 18 \\
\hline Jumlah marga/Genus number & 46 & 52 & 67 & 46 & 48 & 42 \\
\hline Jumlah jenis/Spesies number & 76 & 85 & 112 & 84 & 86 & 77 \\
\hline \multicolumn{7}{|l|}{$\begin{array}{l}\text { Kondisi Populasi Ikan/ } \\
\text { Population Property }\end{array}$} \\
\hline $\begin{array}{l}\text { Indeks Kekayaan-RI } \\
\text { Margalef's Indices }\end{array}$ & 11,25 & 13,67 & 16,61 & 13,59 & 13,41 & 11,90 \\
\hline $\begin{array}{l}\text { Indeks Dominansi (D)/ } \\
\text { Domination Indices }\end{array}$ & 0,06 & 0,05 & 0,05 & 0,03 & 0.06 & 0,05 \\
\hline $\begin{array}{l}\text { Indeks Keanekaragaman/ } \\
\text { Shannon Diversity Index }\end{array}$ & 3,30 & 3,51 & 3,44 & 3,88 & 3,34 & 3.52 \\
\hline $\begin{array}{l}\text { Jumlah gerombolan-N1/ } \\
\text { Hill's diversitry number }\end{array}$ & 27,23 & 33,49 & 31,07 & 48,63 & 28,26 & 33,80 \\
\hline $\begin{array}{l}\text { Jumlah gerombolan-N2/ } \\
\text { Hill's diversity number }\end{array}$ & 16,14 & 19,20 & 18,53 & 32,58 & 16,24 & 21,01 \\
\hline $\begin{array}{l}\text { Indeks Keseragaman-E/ } \\
\text { Evenness Indices }\end{array}$ & 0,76 & 0,79 & 0,73 & 0,88 & 0,75 & 0.81 \\
\hline $\begin{array}{l}\text { Jumlah individu/ } \\
\text { Individual number }\end{array}$ & 787 & 467 & 799 & 450 & 566 & 594 \\
\hline $\begin{array}{l}\text { Kepadatan/Density } \\
\text { (ind } / \mathrm{m}^{2} \text { ) }\end{array}$ & 7,87 & 4,67 & 7,99 & 4,5 & 5,66 & 5,94 \\
\hline \multicolumn{7}{|l|}{$\begin{array}{l}\text { Komposisi/Composition } \\
\text { (Individual number) }\end{array}$} \\
\hline Ikan target-T/Target fishes (\%) & 10,17 & 11,35 & 15,77 & 17,56 & 7.42 & 11,28 \\
\hline lkan mayor-M/Major fishes (\%) & 87,17 & 87,15 & 80,98 & 77,56 & 90,46 & 84,01 \\
\hline $\begin{array}{l}\text { Ikan indikator-l/ } \\
\text { Indicator fishes (\%) }\end{array}$ & 2,67 & 1,50 & 3,25 & 4,89 & 2,12 & 4.71 \\
\hline \multicolumn{7}{|l|}{$\begin{array}{l}\text { Komposisi/Composition } \\
\text { (Species number) }\end{array}$} \\
\hline Ikan target-T/Target fishes (\%) & 30,26 & 29,41 & 31,25 & 33,33 & 25,58 & 29,87 \\
\hline Ikan mayor-M/Major fishes (\%) & 61,84 & 67,06 & 58,04 & 53,57 & 65.12 & 58.44 \\
\hline $\begin{array}{l}\text { Ikan indikator-l/ } \\
\text { Indicator fishes (\%) }\end{array}$ & 7,89 & 3,53 & 10,71 & 13,10 & 9,30 & 11,69 \\
\hline
\end{tabular}

Indeks Shannon: $\mathrm{H}=\Sigma\{(\mathrm{n} / \mathrm{N}) \operatorname{Ln}(\mathrm{n} / \mathrm{N})\}$

Indeks Simpson: $\lambda=\sum\left(n_{1}\left(n_{i}-1\right) /(N(N-1\right.$

Indeks Dominansi: $D=\sum(n / N)^{2}$

di mana:
$n_{i}=$ jumlah ikan jenis ke-i
$\mathrm{N}=$ total individu ikan untuk semua jenis
$\mathrm{H}=$ Indeks Shannon

(Catatan: hasil perhitungan indeks dominansi $=$ hasil perhitungan indeks Simpson)

3. Indeks Hill-diversity number.

$N_{1}=e^{H}$, dan $N_{2}=1 / \lambda$

di mana:

$$
\begin{aligned}
& N_{1}= \text { populasi dari suatu spesies bergerombol } \\
& \text { atau individual yang dijumpai dalam } \\
& \text { jumlah banyak }
\end{aligned}
$$

$\mathrm{N}_{2}=$ populasi dari suatu spesies bergerombol atau individual yang dijumpai dalam jumlah paling banyak

$\mathrm{H}=$ Indeks Shannon

$\mathrm{e}=$ bilangan epsilon/natural

$\lambda=$ indeks Simpson

4. Indeks Keseragaman jenis mengacu pada:

Indeks Pielou: $\mathrm{E}=\{\mathrm{H} / \mathrm{in}(\mathrm{S})\}$

di mana:

$$
S=\text { banyaknya jenis }
$$$$
\mathrm{H}=\text { Indeks Shannon }
$$

\section{HASIL DAN BAHASAN}

Hasil penelitian ini menunjukkan bahwa pada keseluruhan daerah terumbu karang di mana sensus 
dilakukan berhasil teridentifikasi 344 jenis dan 129 marga ikan karang dari 45 suku, dengan variasi antara lokasi berkisar pada 25-112 jenis ikan karang. Kondisi komunitas ikan karang menurut hasil analisis data transek rapid reef assessment disajikan pada Tabel 2.

Tabel 2 menunjukkan bahwa daerah karang sabang memilki kekayaan jenis tertinggi dan kemudian diikuti oleh daerah Bone-Bone, Bandang, Umbuli, Tanjung Pinalang, Karang Merpati, Sabalade, Lukpasateng, Mantopo, dan daerah karang Pulau Bakalan Kecil. Daerah tersebut memiliki jumlah spesies antara 80-112 spesies, di mana indeks kekayaan jenis $(R)$ berkisar antara 12,37-16,61.

Kepadatan ikan karang (jumlah ind. $/ \mathrm{m}^{2}$ ) menurut kriteria Djamali \& Darsono (2005) pada umumnya rendah untuk semua lokasi, tetapi kepadatannya pada Tanjung Pinalang dan Sabang relatif lebih tinggi dari lokasi rapid reef assessment yang lain (Tabel 2, 3, dan Gambar 2). Lokasi Tanjung Pinalang dan Sabang merupakan daerah terbuka dengan relif dasar miring (slope) dan arus yang cukup kuat serta baik untuk ikan-ikan berkoloni besar.

Jumlah populasi ikan bergerombol dengan kategori banyak $\left(N_{1}\right)$ dan banyak sekali $\left(N_{2}\right)$ lebih tinggi dijumpai pada daerah Karang Montopo dan Umbuli (Tabel 2), seperti ditunjukkan oleh nilai indeks Hill- $N_{1}$ (masing-masing 48,63 dan 43,06) dan $N_{2}$ (masingmasing 32,58 dan 29,20 ). Contoh populasi ikan-ikan ini pada umumnya schooling (berkelompok) dan sebagian kecil bersifat soliter tetapi dijumpai dalam jumlah yang besar, contohnya dari jenis ikan pelangi (Pseudanthias spp.), bibisan dan gete-gete (Apogon spp.), gelagah (Cheilodipterus spp.), serinding malam (Sphaeramia spp.), ekor kuning (Caesio spp.), pisangpisang (Pterocaesio spp.), kromis (Chromis spp.), betok (Amblyglyphidodon spp., Pomacentrus spp., Dascillus spp), bayeman (Cirrhilabrus spp.), keling
(Pseudocoris spp.), koja (Halichoeres spp.), dan kembung (Restrelliger kanagurta).

Keanekaragaman ikan karang menurut letak transek rapid reef assessment dapat diklasifikasikan berdasarkan pada kriteria skala seperti tersebut pada Tabel 3, yaitu 21 lokasi transek rapid reef assessment tergolong pada keanekaragaman sedang dan 11 lokasi seperti Bone-Bone, Mandebolu, Bandang, Umbuli, Kendek, Karang Merpati, Pulau Delapan, Sabalade, Lukpasateng, Montopo, dan Bakalan Besar memiliki indeks keanekaragaman yang tinggi. Lokasi yang memiliki keanekaragaman paling rendah adalah Tundusun (Tabel 2 dan Gambar 3).

Indeks keseragaman yang lebih besar dari 0,80 menunjukkan tingkat keseimbangan ekosistem yang sangat tinggi, di mana ini termasuk daerah Karang Tabulang, Bone-Bone, Pulau Bakau, Ganemo, Mandebolu, Pulau Tonggo, Pulau Burung, Matanga, Kendek, Pulau Popisi, Pulau Delapan, Montopo, dan Pulau Bakalan Besar. Lokasi-lokasi lainnya memiliki indeks keseragaman $>0,60$ dan ini tergolong memiliki keseimbangan ekosistem moderat sampai tinggi (Tabel 2), tetapi indeks keseragaman sama dengan 1 (steady state) tidak pernah terjadi di alam, karena tidak ada populasi yang sama persis jumlahnya satu sama lain. Kondisi keseimbangan ekosistem yang tinggi (indeks keseragaman mendekati angka 1) dapat terjadi karena tidak ada kondisi negatif yang ekstrim, di mana dapat mengganggu kesimbangan populasi ikan, seperti pencemaran yang bobot. Adanya gangguan pada habitat ditandai oieh meledaknya (blooming) jumlah satu atau dua populasi yang mampu berkembang dan bertahan pada daerah ekstrim yang terjadi.

Secara faktual, komunitas ikan dari hasil analisis data (Tabel 2) menunjukkan tingkat dominansi yang rendah menurut kriteria Krebs (1989). Dalam hal ini keanekaragaman komunitas dianggap terbaik jika nilai

Tabel 3. Beberapa kriteria untuk menilai kisaran indeks-indeks ekologis keanekaragaman hayati

Table 3. Some criterias to scor the ecological indices of biodiversity

\begin{tabular}{|c|c|c|c|}
\hline $\begin{array}{c}\text { Kisaran dominansi/Ranks } \\
\text { of dominance } \\
\text { Krebs (1989) }\end{array}$ & $\begin{array}{c}\text { Kisaran keanekaragaman/ } \\
\text { Ranks of diversity } \\
\text { Mason (1981) }\end{array}$ & $\begin{array}{c}\text { Kisaran } \\
\text { keseragaman/Ranks } \\
\text { of evenness } \\
\text { Krebs (1989) }\end{array}$ & $\begin{array}{c}\text { Kisaran kepadatan } / \mathrm{m}^{2} / \\
\text { Ranks of square density } \\
\text { Djamali \& Darsono (2005) }\end{array}$ \\
\hline $\begin{array}{l}0,01<D \quad 0,30: \text { Rendah/low } \\
0,30<D \quad 60 \text { : Sedang/fair } \\
0,60<D \quad 1,00: \text { Tinggi/high }\end{array}$ & $\begin{array}{l}\mathrm{H}<2,30 \text { : Rendah/low } \\
2,30<\mathrm{H}<3,45 \text { : Sedang/fair } \\
3,46<\mathrm{H}<5,75 \text { : Tinggi/high } \\
\text { 5,76<H<6,90: } \\
\text { Sangat tinggi/very high }\end{array}$ & $\begin{array}{l}\mathrm{E}<1 \text { : Tinggi/high } \\
0,4<E<0,6 \text { : Sedang/fair } \\
E<0,4 \text { : Rendah/low }\end{array}$ & $\begin{array}{l}\text { 1-5: Sangat jarang/very rare } \\
\text { 5-10: Jarang/rare } \\
\text { 10-20: Cukup melimpah/ } \\
\text { fairly plentiful } \\
\text { 20-50: Melimpah/abundant } \\
\text { >50: Sangat melimpah/ } \\
\text { very abundant }\end{array}$ \\
\hline
\end{tabular}




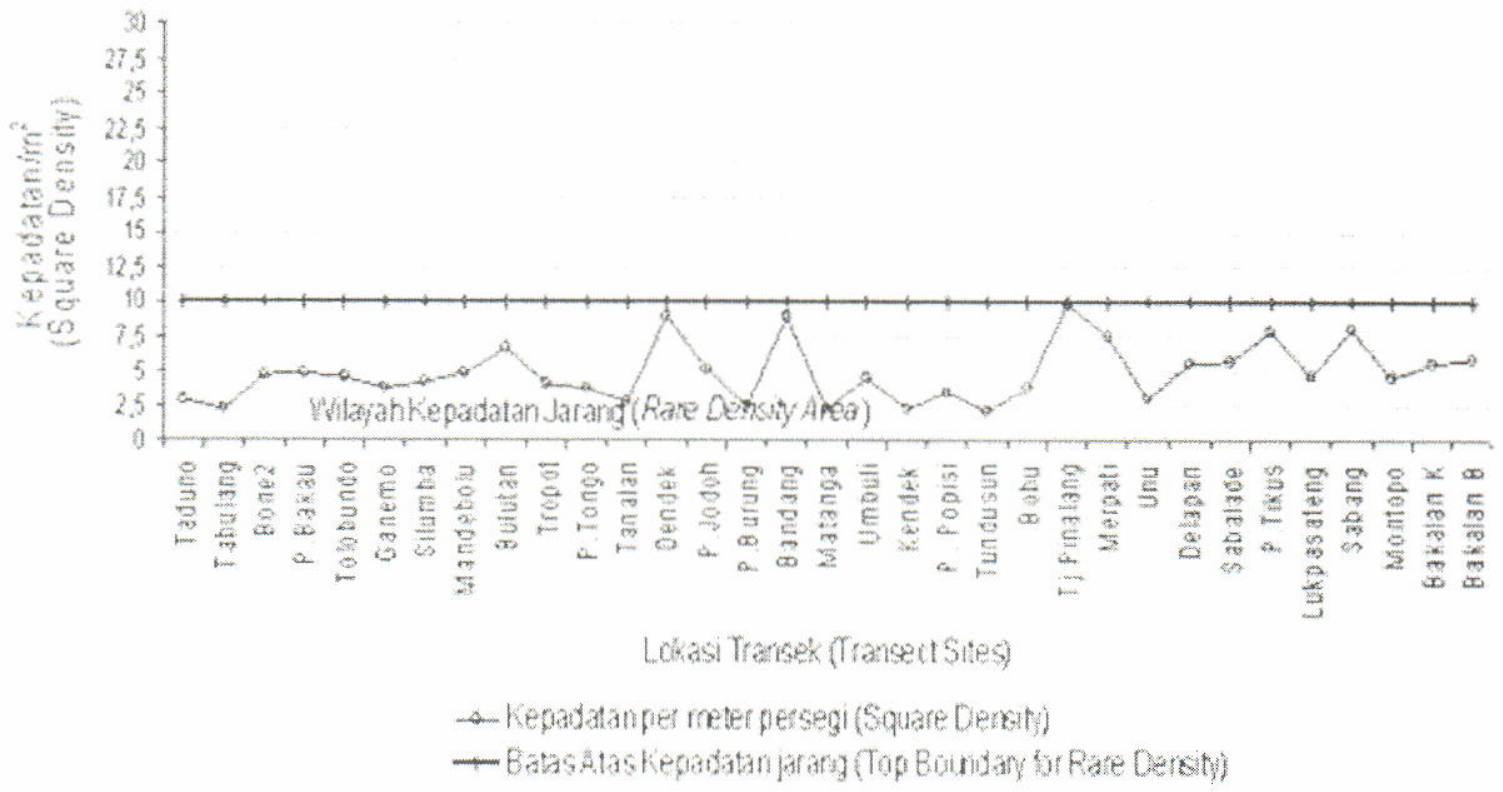

Gambar 2. Kepadatan ikan karang (ind $/ \mathrm{m}^{2}$ ) menurut letak transek rapid reef assessment di perairan karang Banggai Kepulauan.

Figure 2. Reef fish density (ind.$/ \mathrm{m}^{2}$ ) following transect sites in the waters of Banggai Archipelago.

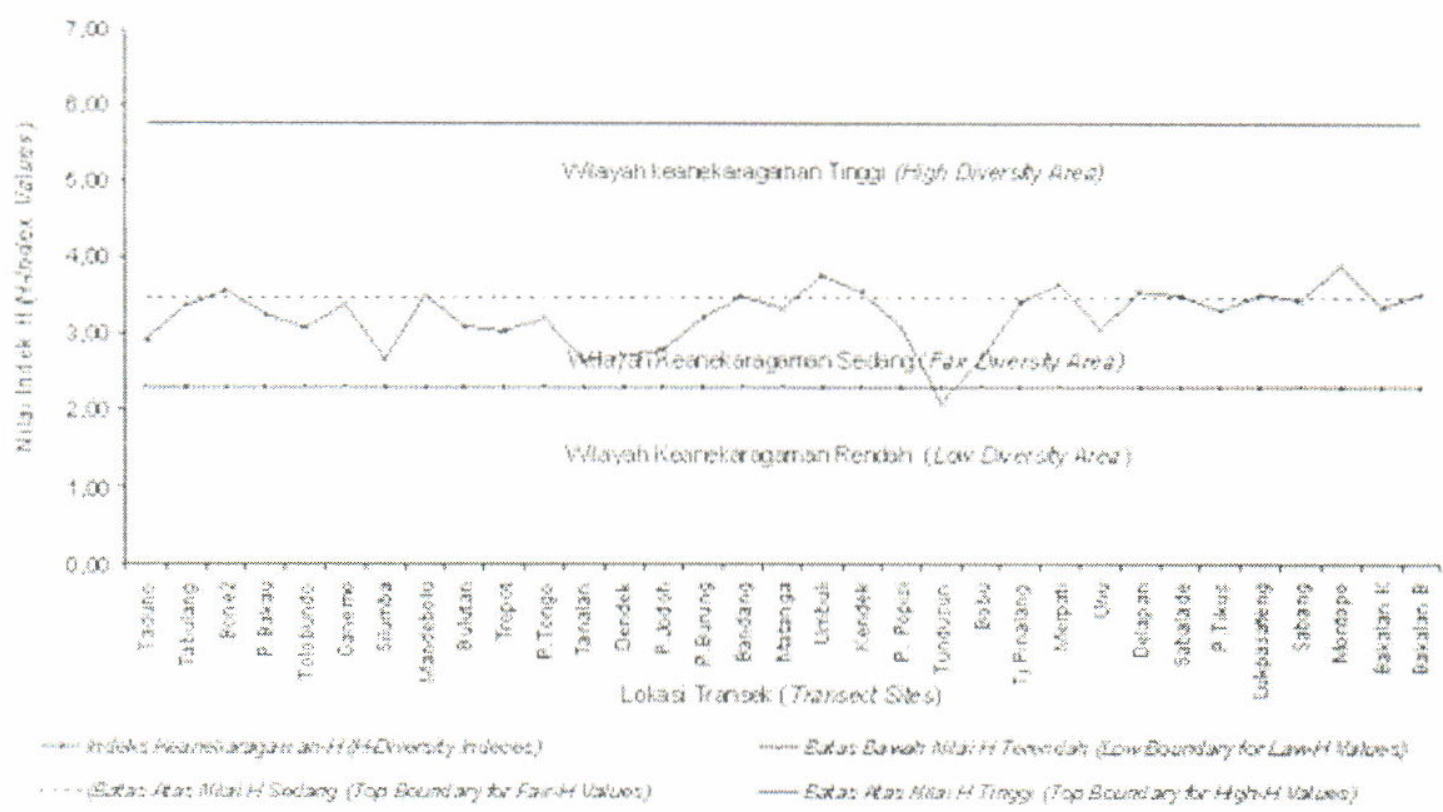

Gambar 3. Indeks keanekaragaman ikan karang menurut lokasi transek rapid reef assessment. Figure 3. Diversity indices of reef fish following rapid reef assessment transect sites.

$D$ mendekati 0 dan terburuk jika nilainya mendekati 1 (misalnya terjadi pada lingkungan hidup yang mengalami tekanan atau pencemaran). Berarti bahwa kisaran nilai dominansi (D) tersebut antara 0 dan 1. Semakin mendekati nilai 0 , menyebabkan nilai Indeks $\mathrm{H}$ akan semakin besar (keanekaragaman hayati dianggap tinggi). Sebaliknya semakin mendekafi 1 , menyebabkan nilai Indeks $H$ semakin kecil (keanekaragaman hayati dianggap buruk) (Krebs, 1989).

Menurut pengelompokan status ikan, baik dalam jumlah individu maupun jumlah jenis (Tabel 2), secara umum kolompok ikan mayor mendominansi komunitas ikan karang di seluruh lokasi penelitian. Lokasi yang memiliki jumlah jenis dan juga jumlah 
individu kelompok ikan target di atas $30 \%$ adalah Mandebolu dan Tanjung Pinalang. Kelompok ikan target yang hanya memiliki jumlah jenis di atas 30\% adalah Bone-Bone, Ganemo, Mandibolu, Tropot, Pulau Jodoh, Pulau Burung, Umbuli, Tanjung Pinalang, Merpati, dan Unu. Kelompok ikan indikator pemakan polyp karang dari suku Chaetodontidae dijumpai paling banyak jumlah jenisnya pada lokasi Karang Bone-Bone, Pulau Tonggo, dan Tanalan, di mana berkisar antara $14-20 \%$ dari seluruh jumlah jenis yang ada. Intensitas kehadiran ikan indikator pada lokasi-lokasi tersebut menunjukkan status karang ke dalam kategori keanekagaraman karang yang relatif baik (Nash, 1989).

Dari daftar jenis ikan karang yang berhasil diidentifikasi di perairan karang Kabupaten Banggai Kepulauan, ada beberapa jenis ikan target yang merupakan komoditi yang memiliki permintaan pasar tinggi dengan harga tinggi pada perdagangan ikan hidup. Jenis-jenis tersebut adalah 5 jenis kerapu (Cephalopholis spp.), 4 jenis kerapu macan (Ephinephelus spp.), kerapu tikus atau lodi (Cromileptis altevelis), 4 jenis kerapu sunu (Plectropomus spp., Variola louti), dan napoleon. Sedangkan golongan non ikan yang juga memiliki permintaan cukup tinggi untuk ekspor perdagangan ikan hidup, yaitu lobster (Panulirus sp.) dan udang pasir (Thenus orientalis).

Dari golongan ikan hias yang bernilai ekonomis tinggi termasuk jenis-jenis dari suku Pomachantidae (Caetodontoplus mesoleucus, Centropyge bicolor, Centropyge tibecen, Pomacanthus navarchus, Pomacanthus imperator, Pomacanthus xanthometopon, Pomacanthus sexstriatus, dan Pygoplites diacanthus), dari suku Chaetodontidae (22 jenis Chaetodon spp., Coradion chrysozonus, Forcipger flavissimus, Hemitaurichthys polylepis, dan Parachaetodon ocellatus), dari suku Pomacentridae (Amphiprion clarkii, Amphiprion frenatus, Amphiprion ocellaris, Amphiprion sandaracinos, Chrysiptera cyanea, Chrysiptera leucopoma, Chrysiptera parasema, Chrysiptera springeri, Chrysiptera rex, Chrysiptera talboti, Dascyllus aruanus, Dascyllus melanurus, Dascyllus reticulatus, Dascyllus trimaculatus, juvenil Neoglyphidodon crossi, Neopomacentrus azysron, Neopomacentrus cyanomos, Neopomacentrus violaceus, juvenis Paraglyphidodon melas, Paraglyphidodon oxyodon, Pomacentrus auriventris, Pomacentrus coelestis, dan Premnas biaculeatus), dari suku Labridae (juvenil Coris gaimard, Diproctacanthus xanthurus, Labroides bicolor, Labroides dimidiatus, dan Labroides pectoralis), dari suku Blenniidae (Meiacanthus grammistes dan Plagiotremus rhinorhynchus), dari suku Gobiidae (Ptereleotris evides), dari suku Zanclidae (Zanclus spp.), dari suku Monacahntidae (Oxymonocanthus longirostris), dan dari suku Balistidae yang mempunyai harga tinggi di pasaran ikan hias dengan nama mendut (Balistoides conspicillum). Jenis yang disebut terakhir ini memiliki corak yang unik, gerakkan yang anggun, jarang ditemukan dan hidup pada kedalaman sekitar $10 \mathrm{~m}$. Pada perairan Kabupaten Banggai Kepulauan, Balistoides conspicillum hanya dijumpai di daerah karang Luksapateng (koordinat $\mathrm{E}: 01,19631^{\circ}-\mathrm{S}$ : $\left.122,91635^{\circ}\right)$

Banggai cardinal dapat dijumpai di 6 lokasi, yaitu Bone-Bone, Tolobundo, Bulutan, Tropot, Pulau Tongo, dan Pulau Bandang. Kepadatan tertinggi Banggai Cardinal dijumpai di Pulau Bandang, Ikan ini dijumpai hidup pada perairan yang tenang dan berenang di selasela duri bulu babi, karang bercabang, dan batuan. Ikan ini sering pula dijumpai di bawah kolong dermaga, kolong rumah pinggir air, dan di pantai-pantai bersampah. Berkaitan dengan tempat ditemukannya, ikan tersebut mudah beradaptasi di mana-mana, tetapi mungkin ada faktor lain yang menyebabkan distribusinya terbatas dan hanya pada perairan Kabupaten Banggai dan Banggai Kepulauan. Faktor keterbatasan sebaran ini diasumsikan adalah bahwa cara reproduksinya atau tempat penelurannya yang spesifik. Menurut informasi dari peneliti pendahulu bahwa ikan ini menyimpan juvenilnya di mulut, seperti yang dilakukan oleh ikan arwana (Scleropages aureus) yang menyimpan telur di mulutnya sampai menetas (sekitar 40 hari). Proses reproduksi ini perlu diteliti lebih jauh dalam kaitannya dengan asumsi keendemikannya.

Jenis-jenis kelompok ikan target maupun kelompok ikan mayor yang merupakan komoditas utama komersil untuk mendukung produksi domestik ikan segar dan ikan olahan (ikan asin) diantaranya banyak ditemukan pada lokasi penelitian. Jenis-jenis tersebut adalah ikan bandeng laut (Chanos chanos), swangi (Myripristis spp., Neoniphon argenteus, dan Sargocentron spp.), kerapu, bibir tebal (Plectorhyncus spp.), kakap atau bambangan (Aprion sp., 5 jenis Lutjanus spp., dan 2 jenis Macolor spp.), lencam (4 jenis Lethrinus spp.), ekor kuning dan pisang-pisang (Caesio cuning, Pterocaesio marri, Pterocaesio pisang, dan Pterocaesio randalli), biji nangka (Mulloidichthys flavolineatus, Parupeneus spp., Upeneus (uzonius, dan Upeneus tragula), ikan-ikan padang lamun (Dischistodus spp.) ikan wrase ( 5 jenis Cheilinus spp., Cheilio inermis, dan Choerodon anchorago), kakatua ( 12 jenis Scarus spp. dan 1 jenis 
Cetoscarus bicolor), baronang (12 jenis Siganus spp.), kembung (Rastrelliger karnagurta), kuwe (Caranx spp. dan Carangoides spp.), barakuda (Sphyraena fosteri), dan ikan-ikan yang selalu mempunyai tingkat produksi tinggi, yaitu ikan teri (Anchoa lyolepis).

Terumbu karang memberikan kapasitas daya dukung yang besar untuk flora dan fauna yang hidup dan tumbuh di dalamnya, terutama ikan karang. Konsep relung ekologi (ecology niche) dan jaring makanan telah memberikan pemahaman yang baik bahwa bagaimana ekosistem terumbu karang menciptakan keanekaragaman jenis biota ikan dan non ikan yang tinggi (Lieske \& Myers, 1997; Nybakken, 1992). Ketika komponen atau fungsi dalam relung ekologi terganggu, ikan akan memberikan respon yang cepat atas kerusakkan niche atau habitatnya. Sehingga kebanyakkan ikan akan menghilang dari tempatnya untuk mencari tempat lain yang menyenangkan.

Kehadiran individu dan/atau jenis ikan yang tergolong dalam suku Chaetodontidae, Pomacantihidae, Pomacentridae, dan Labridae merupakan indikator dari status kelayakan suatu perairan sebagai habitat hidup, dalam hal ini ikan kepe-kepe (Chaetodon sp.) dari suku Chaetodontidae memberikan respon yang signifikan atas perubahan kondisi lingkungan (Edrus \& Syam, 1998). Jika jumlah jenis dari suku tersebut di atas banyak yang hilang, hal ini akan menjadi peringatan (warning) untuk segera melakukan konservasi dan pengkayaan habitat.

Kesehatan terumbu karang dikatakan buruk berkenaan dengan pengertian tutupan karang, keanekaragaman karang, jumlah jenis biota, kesediaan makanan favorit, dan/atau lingkungan perairan yang tidak mendukung. Kelompok ikan indikator dari suku Chaetodontidae (ikan kepe-kepe) memberikan respon yang signifikan pada kondisi menurut salah satu atau lebih dari pengertian di atas. Pengaruh buruknya berkorelasi langsung dengan jumlah individu dan jumlah jenis ikan indikator. Contoh wilayah yang memiliki kondisi perairan karang baik karena berhubungan dengan hadirnya sejumlah jenis ikan kepe-kepe adalah Pulau Tongo dan Tanalan. jumlah jenis maupun jumlah individu tergolong relatif tinggi di kedua wilayah tersebut.

Lingkungan yang buruk dapat direspon secara negatif oleh ikan. Jumlah jenis ikan karang pada masing-masing lokasi memiliki variasi jumlah individu yang lebar. Demikian juga, dengan tingkat kepadatan ikan. Contoh daerah karang yang memiliki kepadatan ikan karang relatif tinggi dibanding lokasi lainnya adalah perairan Tanjung Pinalang dan Sabang. sebaliknya yang memiliki kepadatan rendah adalah hampir di seluruh stasiun penelitian, dan yang paling rendah kepadatannya adalah lokasi Tundusun yang memiliki tingkat kekeruhan tinggi. Hal ini memberikan implikasi bahwa habitat dan kualitas badan air adalah prasyarat utama untuk mendukung peningkatan daya dukung lingkungan sehingga akan mempengaruhi produksi perikanan.

Degradasi potensi sumber daya ikan karang di suatu perairan tidak saja disebabkan oleh cara penangkapan yang ilegal dan merusak, tetapi juga karena adanya tekanan alam dan kegiatan manusia di daratan yang memberikan dampak negatif pada perairan pantai, seperti terjadinya perubahan sedimentasi yang semakin lama semakin memperburuk kualitas perairan.

Indikator ekologis yang menyangkut struktur komunitas ikan karang juga memberikan respon yang berbeda atas lingkungan buruk tersebut. Walaupun nilainya berbeda satu sama lain, tetapi ada kecenderungan di mana indeks keanekaragaman ikan karang di berbagai wilayah kajian semakin meningkat pada lingkungan yang sehat, khususnya pada kondisi ketika terumbu karang dan lingkungan perairan bersama-sama berada pada kualitas yang mendukung, seperti persen tutupan karang tinggi, keanekaragaman karang tinggi dan perairan jernih serta terdapat arus yang kuat. Contoh untuk menggambarkan kondisi keanekaragaman ikan yang tinggi karena didukung oleh kualitas lingkungan yang baik adalah perairan seperti Bone-Bone, Umbuli, Karang Merpati, dan Montopo.

Pada umumnya sebagian besar wilayah perairan karang yang menjadi bahan kajian, indeks dominansi populasi ikan karang tergolong rendah, sebaliknya indeks keseragaman (keseimbangan) populasi tergolong relatif tinggi. Hal ini menujukkan bahwa kondisi habitat yang buruk tidak merupakan hal ekstrim yang secara langsung dapat mengganggu kestabilan ekosistem. Pada kondisi fisik karang yang rusak, hanya perubahan komposisi taksa ikan dan jaring makanan yang berubah, tetapi pada kondisi habitat karang rusak dan diperparah oleh lingkungan perairan yang menjadi buruk, maka baik komposisi taksa, jaring makanan, maupun kepadatan ikan menjadi berubah. Contohnya adalah populasi ikanikan, baik yang bersifat koloni maupun soliter, tidak dapat berkembang untuk meningkatkan jumlah individunya. Fenomena semacam ini ditemukan pada perairan Tundusun, di mana terumbu karang baik tetapi sedimentasi menyebabkan kekeruhan air laut. Pada 
kondisi yang buruk seperti ini kelompok ikan mayor dan indikator sangat terpengaruh dan banyak yang menghilang, sedangkan kelompok ikan target dapat beradaptasi dan bertahan hidup pada relung ekologi (niche) masing-masing, seperti ikan-ikan yang hidup di tempat terbuka, di dasar, meliang di bawah pasir dan pada serpihan-serpihan karang mati, dan ikan yang memakan lumut.

\section{KESIMPULAN}

Bebarapa hal yang dapat disimpulkan dari hasil penelitian ini antara lain:

1. Jumlah jenis ikan karang yang berhasil teridentifikasi adalah 344 spesies, 129 marga, dan 45 suku.

2. Dari 33 lokasi transek, ada 21 lokasi yang memiliki indeks keanekaragaman ikan karang dalam kategori sedang, 11 lokasi masuk pada kategori tinggi dan 1 lokasi (Tundusun) tergolong kategori rendah.

3. Keseimbangan populasi ikan karang dalam komunitasnya masuk pada kategori stabil.

4. Komposisi kelompok ikan karang seperti mayor, target, dan indikator pada semua lokasi transek berada pada kisaran rasio normal, kecuali lokasi transek tundusun.

5. Potensi ikan konsumsi tertinggi dijumpai di Mandebolu dan Tanjung Pinalang.

6. Kepadatan ikan karang tergolong jarang, yaitu di bawah 10 ind. $/ \mathrm{m}^{2}$.

7. Sebaran ikan Banggai Kardinal mengelompok pada daerah tertentu. Dari 33 daerah transek, ada 6 lokasi yang dihuni oleh ikan tersebut, terutama di wilayah perairan selatan.

8. Kondisi perairan karang terburuk dijumpai di Tundusun, yaitu sebagai akibat tingkat kekeruhan perairan yang tinggi.

\section{PERSANTUNAN}

Tulisan ini merupakan kontribusi dari kegiatan riset inventarisasi dan pemetaan sumber daya alam laut Kabupaten Kepulauan Baggai, T. A. 2007, di Badan Koordinasi Survei dan Pemetaan Nasional, CibinongBogor. Atas kerja sama yang baik, dukungan akomodasi dan mobilitas, kami sampaikan terima kasih yang sebesar-besarnya kepada:

1. Staf Bappeda Kabupaten Banggai Kepulauan

2. Staf Badan Pengawas Daerah.

3. Awak speed boat Bawasda

4. Staf Kantor Kecamatan Buko, Bulagi, Bangkurung dan Bokan Kepulauan.

\section{DAFTAR PUSTAKA}

Castro, P. \& M. Huber. 2000. Marine Biology. $3^{\text {rd }}$ ed Boston: McGraw-Hill.

Djamali, A. \& P. Darsono. 2005. Petunjuk Teknis Lapangan untuk Penelitian Ikan Karang di Ekosistem Terumbu Karang. Materi Kursus. Pusat Dokumentasi dan Informasi llmiah-Lembaga IImu Pengatahuan Indonesia. Jakarta.

Edrus, I. N. \& A. R. Syam. 1998. Sebaran ikan hias suku Chaetodontidae di perairan karang Pulau Ambon dan peranannya dalam penentuan kondisi terumbu karang. Jurnal Penelitian Perikanan Indonesia. IV (3): 1998.

English, S., C. Wilkinson, \& V. Baker.1994. Survey Manual for Tropical Marine Resources. Australian Institute of Marine Science, Townsville. Australia

Gomez, E. D. \& H. T. Yap. 1984. Monitoring reef condition. In Coral Reef Management Handbook. R. A. Kenchingt6on \& B. E. T. Hudson (Eds). Unesco Publisher. Jakarta. $171 \mathrm{pp}$.

Gray, J. S. 1997. Marine Bodeversity: Patterns, Threats and Conservation Needs. GESAMP Report and Studies No.62. IMO/FAO/UNESCO IOCNMO WHO /IAEA UN/UNEP International Maritime Org. London. 1997.

Krebs, C. J. 1989. Ecological Methodology. Harper Collins Publishing Inc. New York.

Kuiter, R. H. 1992. Tropical Reef-Fishes of the Western Pacific Indonesia and Adjacent Waters Gramedia. Jakarta.

Lieske, E. \& R. Myers. 1997. Reef Fishes of the World. Periplus Edition. Jakarta. Indonesia.

Ludwig, J. A. \& J. F. Reynolds. 1988. Statistical Ecology. A Primer on Methods and Computing. Jhon Wiley \& Son. New York. 337 pp. 
Nash, S. V. 1989. Reef diversity index survey method for non sspecialist. Tropical Coastal Area Management. 4 (3): p. 14-17.

Nybakken, J. W. 1992. Biologi Laut: Suatu Pendekatan Ekologis. Gramedia. Jakarta.

Odum, E. P. 1975. Fundamental of Ecology. E. B. Sounders Co. Philadelphia. 574 pp.

Rhu. 2008. Banggai cardinal fish, endemik yang terus diburu. Harian Sinar Harapan. 7 April 2008. Sinar
Harapan.co.id. Google Com. 26 Mei 2008, jam 14.00.

Soehartono, T. \& A. Mardiastuti. 2003. Pelaksanaan Konvensi CITES di Indonesia. JICA. Jakarta. 317 $\mathrm{pp}$.

Spalding, M., C. Ravilious, \& E. Green. 2001. World Atlas of Coral Reefs. Berkeley, C. A: University of California Press and UNEPINCMC. 